\title{
Gochnatia polymorpha (Less.) Cabrera (Asteraceae) changes in leaf structure due to differences in light and edaphic conditions
}

\author{
Davi Rodrigo Rossatto ${ }^{1,2,3}$ and Rosana Marta Kolb ${ }^{1}$
}

Recebido em 29/05/2008. Aceito em 11/05/2009

RESUMO - (Gochnatia polymorpha (Less.) Cabrera modifica sua estrutura foliar devido a diferenças na luminosidade e condições edáficas). Gochnatia polymorpha (Less.) Cabrera é uma espécie de Asteraceae com ampla distribuição no bioma cerrado, sendo encontrada em diversas fisionomias florestais da região sudeste do Brasil. O presente estudo descreve alguns caracteres anatômicos foliares dessa espécie e os analisa quantitativamente em função de sua ocorrência nas formações florestais e também das diferenças de luminosidade. Foram encontradas diferenças quantitativas em todos os parâmetros anatômicos analisados. Os resultados demonstram que a alta plasticidade anatômica foliar nesta espécie pode ser considerada como uma vantagem adaptativa que a permite ocorrer em diversos ambientes do cerrado.

Palavras-chave: cerrado, freqüência estomática, mata de galeria, morfologia foliar, plasticidade anatômica

ABSTRACT - (Gochnatia polymorpha (Less.) Cabrera (Asteraceae) changes in leaf structure due to differences in light and edaphic conditions). Gochnatia polymorpha (Less.) Cabrera is a widespread Asteraceae species found in different physiognomies of cerrado (Neotropical savanna) and in forest formations of southeast Brazil. This study describes some leaf anatomy characteristics of this species and quantitatively evaluates them in relation to different environments, as well as under different light conditions. We found quantitative differences in all anatomical parameters analyzed. The results demonstrate that high leaf anatomy plasticity is an adaptive advantage that allows this species to occur in diverse cerrado conditions.

Key words: anatomical plasticity, gallery forest, leaf morphology, Neotropical savanna, stomatal frequency

\section{Introduction}

Phenotypic plasticity is related to the ability of an organism to alter its physiology or morphology due to interaction with environmental factors such as light, water and temperature (Stearns 1989, Scheiner 1993). Plant species with great capacity for plasticity in characters linked to survival factors present great adaptive advantages in transitional, heterogeneous and unstable environments. The changes produced can facilitate the exploitation of new niches, resulting in an increase in environmental tolerance (Via 1993).

The Neotropical savanna of Brazil, locally known as "Cerrado", covers about 2 million $\mathrm{km}^{2}$, representing ca. $22 \%$ of the country's land surface. Seasonal precipitation, soil fertility, drainage and fire regimes are the key factors determining the distribution of the biome (Ratter 1992, Furley 1999). Two distinct seasons, a very strong dry season during the southern winter and a wet season in summer characterize seasonal precipitation. Most of the "Cerrado" soils are deep and well-drained, with superficial layers that dry out completely during the dry season, being dystrophic, with low $\mathrm{pH}$ and low availability of calcium and magnesium and presenting high aluminum concentrations (Furley \& Ratter 1988, Haridasan 1992). The nutrient-poor, acid soils represent a limiting factor for plant growth in this region (Haridasan 2001), thus the species that live there should have specific adaptations (Ratter et al. 1997).

Cerrado vegetation has remarkable physiognomic variation, generally characterized by a grass-woodland gradient, resulting in several physiognomies (Oliveira-Filho
\& Ratter 2002). This grass-woodland gradient promotes ecotone regions, where the environment shows several unstable characteristics. Due to the great territorial reach and the differences found in physiognomies, the environment of the Brazilian Cerrado is extremely transitional and unstable. Among its physiognomies we find two main forest types: "cerradão" and gallery forest. "Cerradão" is a forest formation, encountered in both mesotrophic and dystrophic soils, with crown cover of 50 to $90 \%$, made up of trees, often $8-12 \mathrm{~m}$ tall or even taller. This formation generally occurs in several ecotone regions with grass and forest formations. Plants that occur in these systems present many xeromorphic and sclerophyllous characteristics (Oliveira-Filho \& Ratter 2002). Gallery forest is a vegetation type that follows small rivers, being characterized by perennial species of typical moist forest. The key factor for the occurrence of gallery forest within the Cerrado Biome is high soil water availability throughout the year and a great amount of soil nutrients (Oliveira-Filho \& Ratter 2002).

Morpho-anatomical characteristics of plants are greatly influenced by environmental factors, being associated with climate (light and amount of rainfall), physical and chemical characteristics of the soil, relief and altitude (Givnish 1984). These factors vary in space and time and can be limiting to the establishment and growth of the vegetation. Leaves are the plant organs most exposed to environmental conditions and the changes in their structure have been interpreted as adaptations to specific environments (Fahn 1986). The evaluation of anatomical characteristics of the leaves, in widespread species, present in a range of vegetation,

\footnotetext{
Universidade Estadual Paulista, Departamento de Ciências Biológicas, Faculdade de Ciências e Letras, Assis, SP, Brasil

2 Universidade de Brasília, Instituto de Biociências, Departamento de Botânica, Laboratório de Fisiologia Vegetal, Brasilia, DF, Brasil

3 Corresponding author: drrossatto@gmail.com
} 
being exposed to environmental differences, has the main aim of elucidating the processes of gas exchange and water economy in relation to leaf structure, and purposing to identify predictive ecophysiological responses to environmental stress (Abrams et al. 1994).

The family Asteraceae is well represented in several regions of the tropics and sub-tropics. Occupation of different ecological niches by species of this family is a result of phenotypic plasticity, manifested generally in internal structural changes related mainly to leaf anatomy (Cronquist 1981). The leaf anatomy of Asteraceae species in Neotropical regions is poorly understood and most works are descriptive (Sajo \& Menezes 1994, Melo-de-Pinna 2004, Milan et al. 2006). Gochnatia polymorpha (Less.) Cabrera is a widespread tree species of Asteraceae (Mutisieae tribe) in Brazil, being present in several physiognomies of the Cerrado (Mendonça et al. 1998) and in the semideciduous forest in southeast Brazil (Tabanez et al. 2005), areas where this species has high relative density and dominance (Gomes et al. 2004). This species is mainly used in forest restoration (Durigan et al. 2003), being known for its medicinal (Sacilotto et al.1997, Catalan et al. 2003) and wood uses (Lorenzi 2002).

Due to the occurrence of this species in several environments, we expected leaves to show anatomical plasticity in response to differences in edaphic and light conditions. The aim of this study was to analyze the effects of different environmental factors, in different leaf structures, in a population of this widespread species. For this reason, we verified the effects of two light conditions and the effects of two edaphic conditions, comparing leaves of plants in shade and sun, present on the edge and inside "cerradão" forest, and leaves of plants growing in "cerradão" and in gallery forest, physiognomies with different soil types.

\section{Material and methods}

Study area - This study was conducted at the Assis Ecological Station

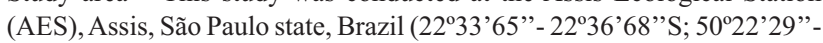
$\left.50^{\circ} 23^{\prime} 00^{\prime \prime} \mathrm{W}\right)$. The vegetation is a Neotropical savanna characterized as cerrado lato sensu (Oliveira-Filho \& Ratter, 2002), where "cerradão" physiognomy predominates (Durigan et al. 1999). In AES, this forest formation is found in "Latossolo vermelho distrófico", characterized as dystrophic oxisoils, being highly weathered, well drained, possessing high content of hydrous oxides of iron and aluminum, low cation exchange capacity and low organic matter content (Juhász et al. 2006). Gallery forest occurs near water sources and bordering small rivers, being characterized by hydromorphic soils ("Gleissolo háplico argissólico"), possessing high organic matter, higher cation exchange capacity and higher water content (Juhász et al. 2006). According to Köppen's classification, climate at the Assis Ecological Station is transitional between Cwa and Cfa, with rainfall concentrated in summer. Annual precipitation is less than $1400 \mathrm{~mm}$ and temperatures are around $21.8^{\circ} \mathrm{C}$. The dry season occurs between June and September, and the wet season between October and May (Secretaria do Meio Ambiente 1997). The study site has been protected from fire for at least 40 years (Durigan et al. 1999).

Species description and anatomical study - Gochnatia polymorpha is a tree with suberized, twisted trunks. The leaves are simple, alternate, elliptical, approximately $12 \mathrm{~cm}$ in length and $4 \mathrm{~cm}$ in width. The leaf blade is variable in color, ranging from dark green to light gray-green (Durigan et al. 2004). This species occurs in several physiognomies in AES, including cerrado, "cerradão" and gallery forest (Durigan et al. 1999). The plant material was collected from an individual tree growing in "cerradão" and was deposited in the non-official herbarium of the Departamento de Ciências Biológicas, Unesp - Assis, being identified by Dra. Giselda Durigan (Instituto Florestal, Assis, SP). In order to evaluate the effects of different edaphic conditions, leaf samples of G. polymorpha were collected from adult individuals in "cerradão" $\left(22^{\circ} 36^{\prime} 01\right.$ "S - $50^{\circ} 22^{\prime} 17^{\prime}$ 'W) and in gallery forest $\left(22^{\circ} 35^{\prime} 52^{\prime \prime} \mathrm{S}-50^{\circ} 22^{\prime} 21^{\prime \prime} \mathrm{W}\right)$ areas, in January 2005 . In both, plants were subjected to similar light conditions, however they occurred in areas with different soil types (as described in study area). To study the effect of luminosity, sun and shade leaves were collected, at the same time, from individuals present at the edge $\left(22^{\circ} 36^{\prime} 08^{\prime \prime} \mathrm{S}-50^{\circ} 22^{\prime} 24^{\prime \prime} \mathrm{W}\right)$ and inside $\left(22^{\circ} 36^{\prime} 01\right.$ ” S - 50'22'22”'W) “cerradão" forest. In both areas, light intensity was measured with a spherical sensor coupled to a Li-cor photometer ( $\mathrm{Li}$ 250A, Biosciences, Lincoln, USA), during an entire sunny day in January 2005. Temperature was measured with a common thermometer. Plants at the edge of "cerradão" were submitted to higher values of light intensity and temperature than plants living inside "cerradão" (Fig. 1-2). For all the situations analyzed, leaves were collected from the fourth node. Each collected sample consisted of a middle fragment of fully expanded leaves (between the main vein and the leaf margin) from six randomly chosen individuals. All individuals were over 20 centimeters in diameter at breast high, and were sampled in the same region with a minimum distance of 30 meters. Samples were fixed in FAA 70, dehydrated in a graded ethanol series, infiltrated and embedded in paraffin and cut into $8 \mu \mathrm{m}$ sections. The cross sections were stained with astra blue-basic fucsine, being permanently mounted in Entellan ${ }^{\circledR}$. Measurements of leaf characters (cuticular thickness, as well as epidermis of abaxial and adaxial surfaces, palisade and spongy parenchyma thickness) were 50 in 10x objective lens for each sample. Stomata and trichome frequency, as well as length of guard cell and width of stomatal complex, were obtained using epidermal prints of dissociated material in $1 \%$ sodium hypochlorite solution and stained with safranin. The leaves are hypostomatic, and stomata counts were made only on the abaxial surface. The counts and measurements were made in 3 fields per sample in 10x objective lens. Stomata size was measured in 30 stomata per field. The relationship between stomatal and trichome frequency and between leaf and palisade parenchyma thickness was analyzed by simple linear regression. The significance of statistical differences between the treatments ("cerradão" x gallery forest and sun x shade) was determined utilizing student T-test ( $\alpha=0.05)$.

\section{Results and discussion}

Leaf Anatomy - Leaves of G. polymorpha are bifacial, with bi- or triseriate palisade parenchyma and welldeveloped spongy parenchyma. The epidermis of the adaxial surface is thicker than the epidermis of the abaxial surface, and generally had two layers of cells. In some cases, the epidermis of the adaxial surface consisted of three layers. These layers (second and third ones) also can represent a hypodermis; however this was not investigated by an ontogenetic study. The cuticle is thick on the adaxial surface and thin on the abaxial surface. Leaves are hypostomatic, with anomocytic stomata that are raised above the level of neighboring ordinary epidermal cells. Tector trichomes are present only on the abaxial surface (Fig. 3-6).

The leaves have many sclerophyllous characteristics: thick leaves with great amount of palisade parenchyma, thick cuticle, presence of trichomes and a well-developed vascular system. The lateral veins have bundle sheaths 
with fibers and parenchymatous cells that are thickwalled, with extensions towards the epidermis (Fig. 3-6). The presence of fibers surrounding the vascular bundles is characteristic in Mutisieae (Melo-de-Pinna 2004), indicating phylogenetic trends.

Cuticular thickness - Quantitative assessment of the cuticle on the adaxial surface shows that this character varies in all analyzed conditions (Tab. 1). A thicker cuticle was observed on leaves of individuals growing under more light and lower humidity conditions (in sun condition and "cerradão" physiognomy). The significantly thicker cuticle may be a mechanism to conserve water in the drier habitat ("cerradão") or in lighter, hotter conditions (sun-leaves). According to Pallardy (1981) the cuticle restricts water vapor loss, being the simplest method to conserve leaf water. Thinner cuticles were indicative of major water abundance, in the case of gallery forest, or minor light intensity, in the case of shade leaves (Tab.1). Hlwatika \& Bhat (2002) reported that species living near streams had thinner cuticle than the distant species, showing clear humidity influence in this character. According to these authors, thick cuticle appears to be characteristic of species that transcend different environments, as is the case of $G$. polymorpha. This characteristic might help this species to colonize and grow in different environments. Temperature may also be a responsible stimulus or environmental factor that affects cuticular thickness. In lighter environments, the cuticle acts like a spendthrift, wasting excess light that could increase leaf temperature and damage mesophyll cells (Fahn \& Cutler 1992).

Epidermis - The epidermis of the adaxial surface shows plasticity in cerradão-gallery forest and sun-shade conditions. In both cases, the epidermis of the adaxial surface was thicker in conditions of high luminosity and low humidity (Tab. 1). In "cerradão" condition all sampled individuals had an epidermis with a third cell layer on the adaxial surface (Fig. 3). Large cells with thick cell walls characterized the ground cell layers. Generally, subepidermal layers originated by protodermal or fundamental meristem exhibit big cells with thin cell walls related to water storage (Fahn \& Cutler 1992). However, big epidermal cells with thicker cell walls can protect photosynthetic tissue by dispersal of excessive luminosity, when a species grows in poor soils (Feller 1996), as is the case of "cerradão" soils. In shade and sun leaves, the epidermis of the adaxial surface had two layers of cells (Fig. 5-6), however in the last ones, the cells were bigger, resulting in a larger tissue (Tab. 1). Due to high luminosity, the thickness of the epidermal layer operates as light and heat waster and barrier to water losses. On the abaxial surface differences occur only between sun and shade leaves. In these cases, leaves with more luminosity had a thicker epidermis. The differences were due to the size of the epidermal cells (Fig. 5-6, Tab. 1).
Palisade parenchyma - Differences are encountered between gallery forest and "cerradão" and between sun and shade leaves (Tab. 1). In gallery forest the palisade parenchyma was thicker than in "cerradão", showing that humidity or soil characteristics can clearly influence the thickness of this tissue. The gallery forest soils tend to be more fertile than "cerradão" soils, generally characterized as dystrophic soils (Haridasan 2001). Concerning luminosity, sun leaves had thicker palisade parenchyma than shade leaves. Leaves exposed to high irradiation conditions or sun leaves, generally develop a well-defined palisade parenchyma and those that grow under low irradiation conditions or shade leaves, are thinner and present a less defined palisade layer than the former (Larcher 2003, Vogelmann 1993). Tissue distribution in the mesophyll remains constant in the G. polymorpha leaves investigated, in many cases we encountered an incomplete third palisade stratum, a fact also found in E. angustifolia, a Eurasian tree naturalized in Rio Negro, Argentina (Klich 2000). Isanogle (1944) proposes that light does not affect the number of cell layers but, instead, it affects the length of the palisade cells; this was not the case for G. polymorpha that presented an increase in palisade cell layers (Fig. 5-6). It was visible in the field that $G$. polymorpha sun leaves, like xeromorphic leaves, had minor leaf area when compared to shade and mesophytic leaves. In high luminosity conditions the greater palisade parenchyma layers may be compensation to the minor leaf area in sun leaves (Turner 1994).

Spongy parenchyma - Differences were encountered only between gallery forest and "cerradão" environments. The spongy parenchyma was thicker in gallery forest individuals than in "cerradão" (Tab. 1). Mantuano et al. (2006), in a study of Erythroxylum populations in different "restinga" types, showed that this trait did not vary in the populations in response to microhabitat type. According to Jackson (1967) the spongy parenchyma responds little to environmental changes, a fact found for this tissue in sun and shade leaves (Tab. 1). The thicker spongy parenchyma could be a mechanism to increase concentration of air in the mesophyll, promoting an increase in photosynthetic rates in leaves of individuals living in an environment with higher water availability (Pearce et al. 2006).

Stomatal size - Stomatal length and width varied in all studied situations. In gallery forest the stomata were bigger than in "cerradão" forest, and shade leaves also presented bigger stomata than sun leaves (Tab. 1). Small stomata appear in environments with high luminosity and low humidity, seeming to be characteristic of xeromorphic leaves (Shields 1950). In many studies stomatal dimensions show plasticity in response to environmental conditions. Leaves with smaller stomata are more efficient in the use of water resources and the differences in stomatal pore size have 

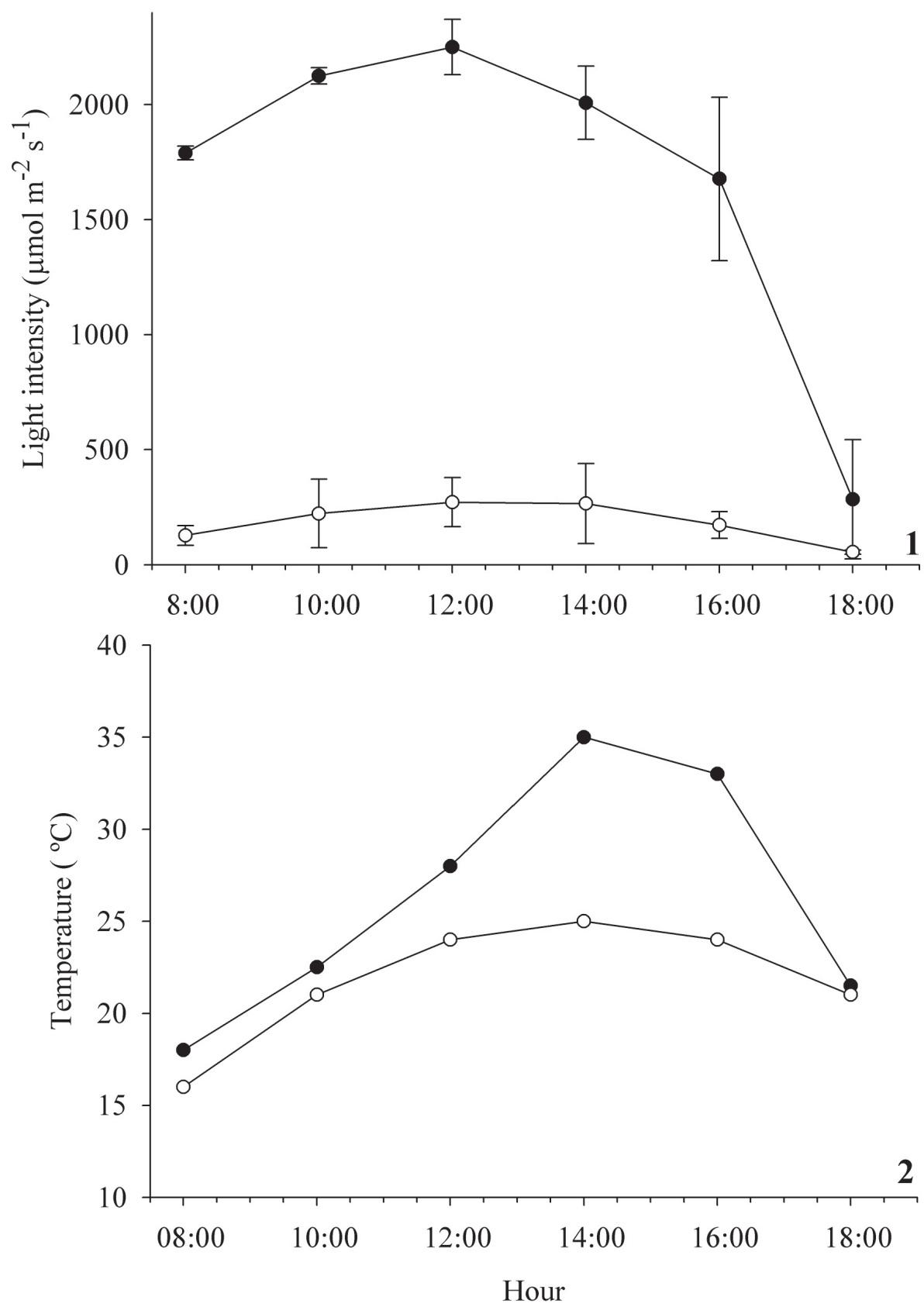

Figures 1-2. Diurnal curve of light intensity (1) and temperature (2) under sun and shade conditions in "cerradão" forest site. Data represent the mean \pm s.d. ( $\mathrm{n}=5$ ). (•) Sun; ( $)$ Shade.

a greater effect on water diffusion than on $\mathrm{CO}_{2}$ diffusion (Abrams et al. 1994).

Stomatal frequency - Stomatal frequency was higher in "cerradão" and in sun leaves (Tab. 1). In "cerradão" and in sun leaves, the stomata were more frequent and smaller than the stomata in gallery forest and in shade environment. High smallstomata frequencies are usually characteristics of xerophytic leaves (Fahn 1964). Plants grown under high light intensities also show high stomatal frequency. This characteristic allows more efficient gas exchange, because an increase in stomatal number is associated with higher stomatal conductance and consequently with higher photosynthetic rates (Pearce et al. 2006, Galmes et al. 2007). Significantly higher stomatal frequency on the abaxial surface in "cerradão" and in sun leaves also suggests better control over transpiration, avoiding excessive water loss (Weyers \& Meidner 1990).

Trichome frequency - Trichome frequency was higher in environments with higher luminosity and lower water 

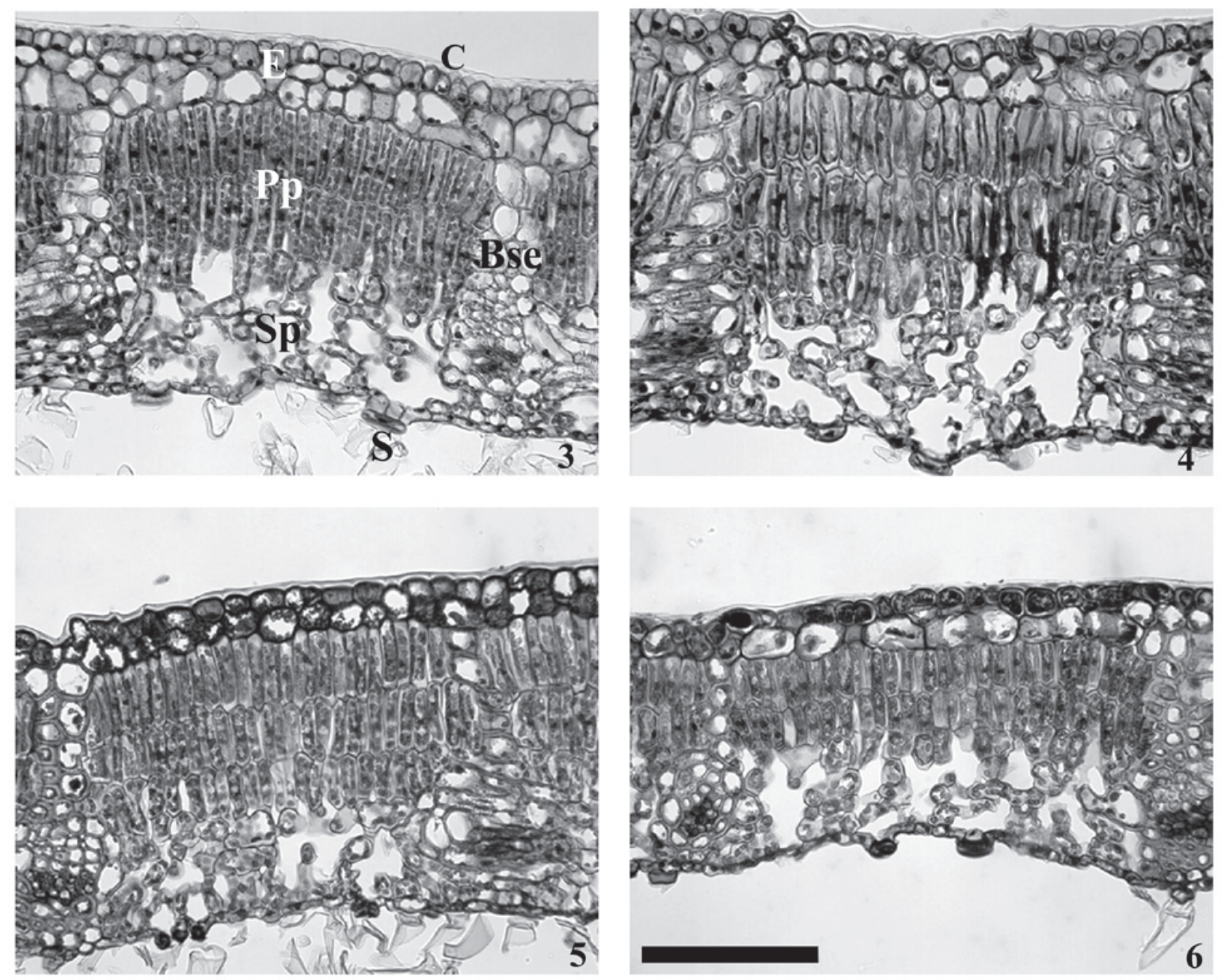

Figures 3-6. Cross-sections of leaves of Gochnatia polymorpha (Less.) Cabrera (Asteraceae). 3. "cerradão". 4. gallery forest. 5. sun leaf. 6. shade leaf. C= cuticle, E $=$ epidermis of adaxial surface, $\mathrm{Pp}=$ palisade parenchyma, $\mathrm{Sp}=$ spongy parenchyma, $\mathrm{S}=$ stoma, $\mathrm{Bse}=$ bundle sheath extension. Scale bar $=100 \mu \mathrm{m}$.

availability (Tab. 1). Gianoli \& Gonzalez-Teuber (2005) showed differences in trichome frequency in plants growing in different conditions of humidity: the plants growing in low levels of humidity had higher trichome frequency. High trichome frequency in sun leaves represents an adaptation to avoid increase in leaf temperatures and also is reported to reduce water loss. Leaf pubescence reduces the absorption of incident solar and environmental radiation, which results in the reduction of leaf temperature (Klich et al. 1997), hence reducing heat load and minimizing the need of transpirational cooling for keeping leaf temperature within functional ranges (Ehleringer \& Björkman 1978). When we analyze all the data of the treatments together, there is a clear relationship between stomatal and trichome frequency, as shown in Fig. 7. An increase in stomatal frequency is clearly related to an increase in trichome frequency $\left(\mathrm{r}^{2}=0.78, \mathrm{p}<0.01\right)$, confirming that pubescence on the abaxial epidermis surface is a characteristic that confers stress resistance. This is because hairs may affect transpiration by influencing the water diffusion boundary as the indumentum decreases air movements on the leaf surface, creating a zone of still air and reducing diffusion of water vapor from the leaf interior to the atmosphere (Ehleringer et al. 1976).

Leaf thickness - Plants growing in direct sunlight had leaves with greater thickness (Tab. 1). The direct relationship between leaf thickness and light intensity has been observed in a number of species (Björkman 1981, Paiva et al. 2003). This characteristic is mentioned as a structural mechanism that increases photosynthesis per unit leaf area and enables better water-use efficiency (Boardman 1977). Analyzing all the data (Fig. 8) we encountered a good relationship between leaf thickness and palisade parenchyma $\left(r^{2}=0.94\right.$, $p<0.01$ ), showing that the main tissue responsible for increasing leaf thickness is the palisade parenchyma. This layer contributed approximately $50 \%$ of leaf thickness; similar values are found in Mediterranean species (Gratani et al. 2006). Thicker leaves in gallery forest occurred because of an increase in palisade and in spongy parenchyma thickness (this layer was responsible for $32 \%$ of leaf thickness in this condition) which promotes higher photosynthetic rates due the increase in $\mathrm{CO}_{2}$ concentration (Pearce et al. 2006). 
Table 1. Measurements of leaf characters ( $\mu \mathrm{m}$; mean \pm s.d.) and stomatal and trichome frequency (mean number per mm² \pm s.d.) for Gochnatia polymorpha (Less.) Cabrera (Asteraceae). *In this study we considered the two layers of cells above the palisade parenchyma as adaxial surface epidermis. Different letters represent statistical differences according t-test $(\mathrm{p}<0,05)$.

\begin{tabular}{|c|c|c|c|c|}
\hline & \multicolumn{4}{|c|}{ Conditions } \\
\hline & Cerradão & Gallery Forest & Sun & Shade \\
\hline Adaxial surface cuticle & $5,42 \pm 0,46 \mathrm{a}$ & $3,65 \pm 0,25 \mathrm{~b}$ & $5,06 \pm 0,64 \mathrm{a}$ & $3,20 \pm 0,24 b$ \\
\hline Adaxial surface epidermis* & $39,70 \pm 3,28 \mathrm{a}$ & $29,08 \pm 2,39 b$ & $30,40 \pm 2,62 \mathrm{a}$ & $26,62 \pm 1,63 b$ \\
\hline Palisade parenchyma & $105,68 \pm 6,65 \mathrm{a}$ & $114,71 \pm 5,85 b$ & $101,54 \pm 4,90 \mathrm{a}$ & $72,00 \pm 15,37 b$ \\
\hline Spongy parenchyma & $54,66 \pm 4,76 \mathrm{a}$ & $72,96 \pm 3,00 \mathrm{~b}$ & $54,17 \pm 6,67 \mathrm{a}$ & $52,21 \pm 4,74 \mathrm{a}$ \\
\hline Abaxial surface epidermis & $5,86 \pm 0,58 \mathrm{a}$ & $5,88 \pm 0,74 \mathrm{a}$ & $6,34 \pm 0,35 \mathrm{a}$ & $5,31 \pm 0,42 b$ \\
\hline Leaf thickness & $211,32 \pm 5,25 \mathrm{a}$ & $226,28 \pm 7,63 b$ & $197,52 \pm 10,72 \mathrm{a}$ & $159,37 \pm 17,94 \mathrm{~b}$ \\
\hline Stomatal length & $22,81 \pm 2,35 \mathrm{a}$ & $27,15 \pm 1,20 b$ & $19,10 \pm 0,89 \mathrm{a}$ & $26,04 \pm 1,52 b$ \\
\hline Stomatal width & $25,34 \pm 2,35 \mathrm{a}$ & $30,87 \pm 2,20 b$ & $21,17 \pm 0,26 \mathrm{a}$ & $22,26 \pm 0,81 \mathrm{a}$ \\
\hline Stomatal frequency & $389,90 \pm 10,50 \mathrm{a}$ & $362,70 \pm 11,00 \mathrm{~b}$ & $427,20 \pm 21,80 a$ & $268,60 \pm 11,50 b$ \\
\hline Trichome frequency & $67,68 \pm 2,30 \mathrm{a}$ & $49,20 \pm 3,50 b$ & $90,80 \pm 2,80 \mathrm{a}$ & $30,91 \pm 17,53 b$ \\
\hline
\end{tabular}

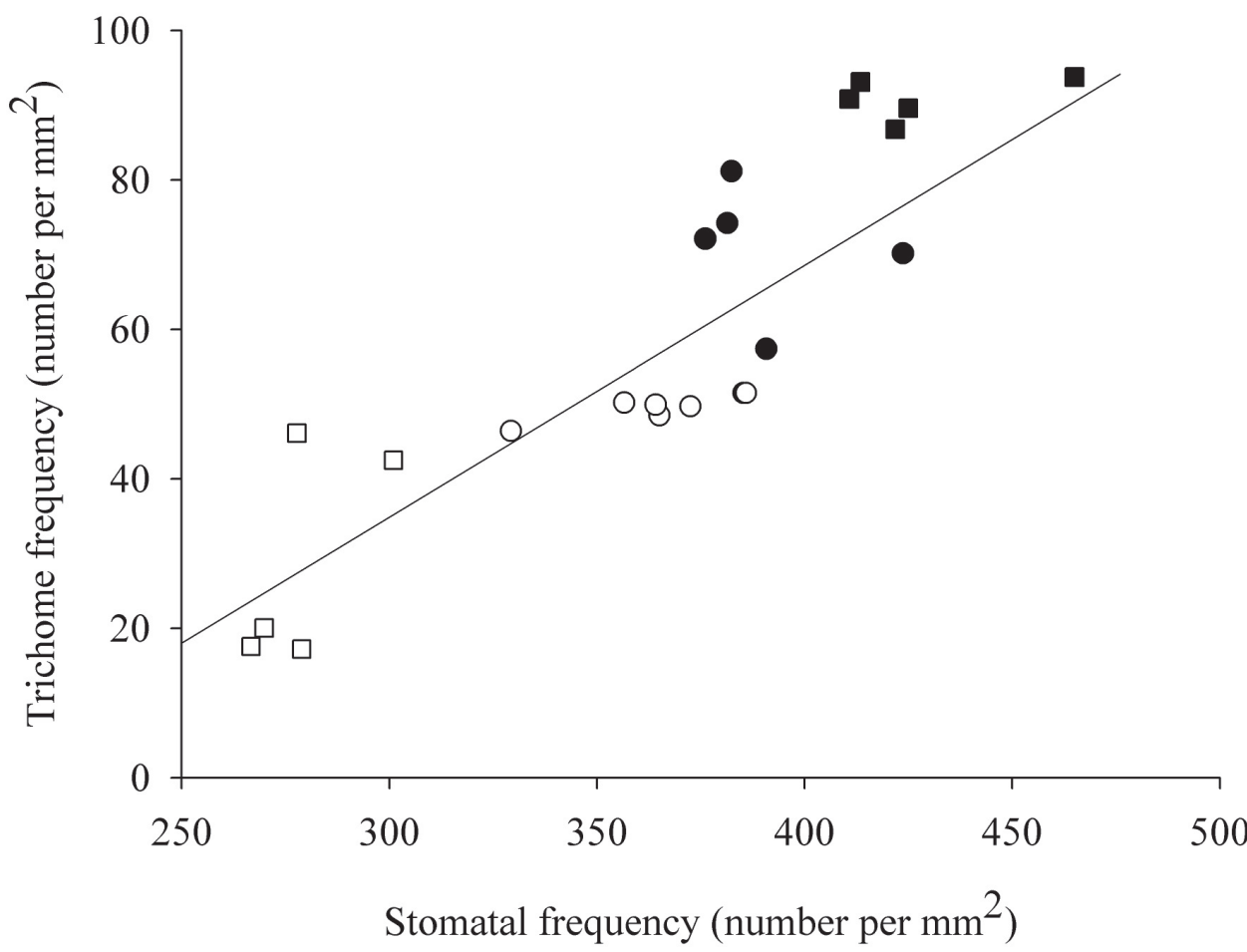

Figure 7. Relationship between trichome and stomatal frequency in Gochnatia polymorpha (Less.) Cabrera (Asteraceae) leaves. (घ) Sun leaves; ( $\square$ ) Shade Leaves; (•) "Cerradão" Forest; (०) Gallery Forest.

The anatomical differences encountered between "cerradão" and gallery forest leaves may be motivated by differences in soil properties such as texture, nutrients and also soil humidity. The "cerradão" soils are dystrophic, with low quantities of nutrients like N, P and $\mathrm{K}$ and greater amounts of Al, which may cause scleromorphism in “cerradão" species (Haridasan 2001, Juházs et al. 2006). Medina et al. (1990) showed that sclerophyllous structure is not necessarily an adaptation to drought, but is probably selected in nutrient poor environments such as phosphorous deficient soils in both humid and semi-arid areas.
Different luminosity conditions clearly affect the structures related to avoiding water loss (cuticle, epidermis and trichome frequency) and the structures related to photosynthesis (parenchyma, stomatal size and stomatal frequency). The sun leaves, normally exposed to higher solar irradiance and lower air humidity, are smaller, more slender and thicker than the shade leaves. In our field observations the color varies between the leaves, from silvery gray-green in sun conditions to dark green in shade. When compared to shade leaves, sun leaves have a higher mesophyll proportion and stomatal 


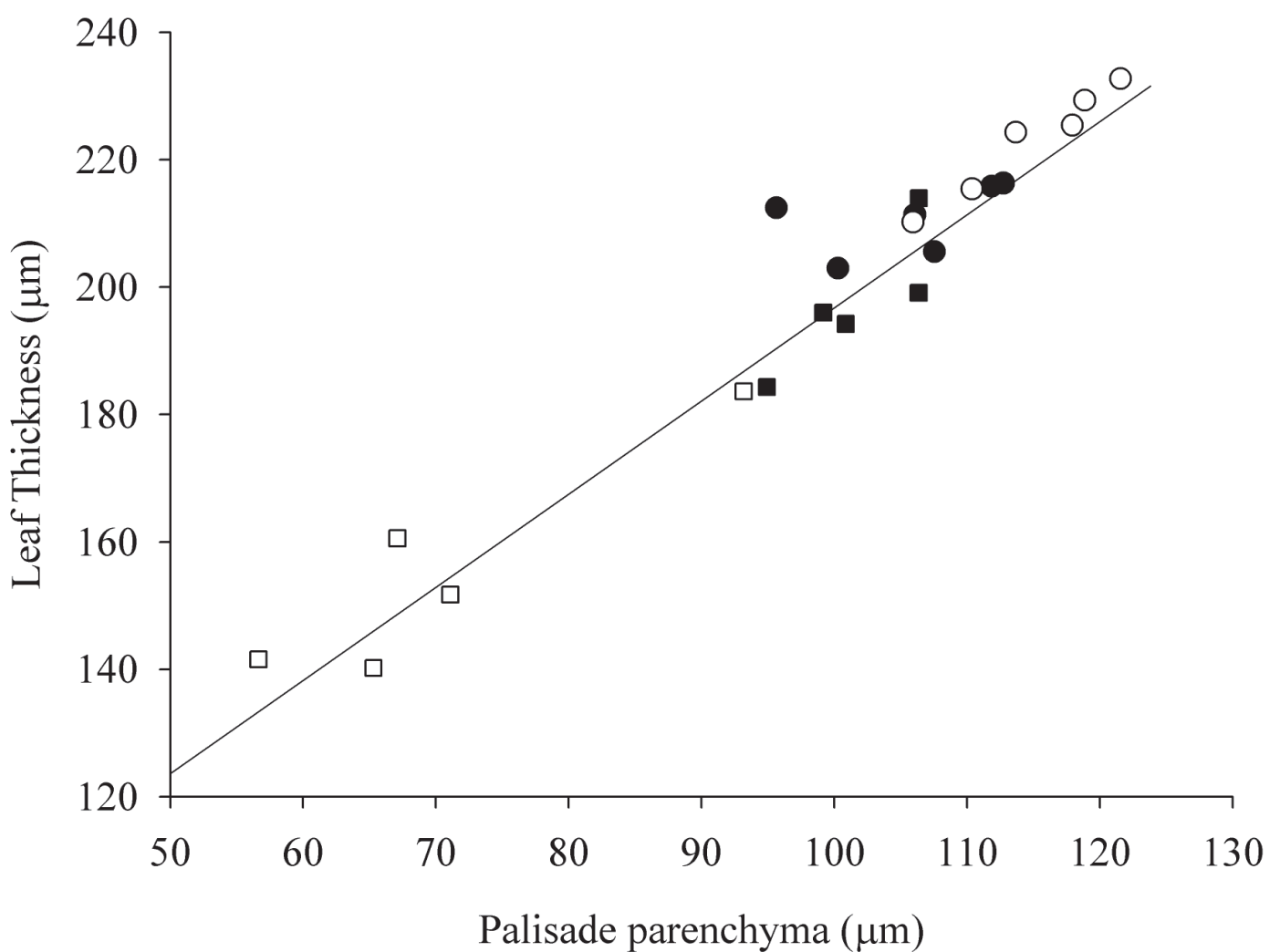

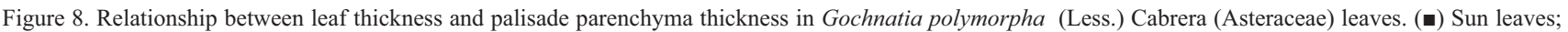
(口) Shade Leaves; (•) "Cerradão" Forest; ( ( ) Gallery Forest.

frequency. Smith et al. (1997) suggest that the presence in shaded environments of thin laminar leaves, with stomata only on the abaxial surface, may have evolved as a result of selective pressure to enhance light capture while avoiding the detrimental effect of exposing the stomata directly to sunlight and minimizing transpirational water-loss. Possibly, differences in leaf anatomy could bring physiological adaptations to different light levels (Dias et al. 2007).

G. polymorpha exhibited high phenotypic plasticity; its leaf structure changed to suit the particular environment. According to Turner (1994), sclerophylly may have several advantages under a wide range of environmental conditions, so leaf-anatomy variability in this species may be considered an adaptive advantage that enables leaves to develop and function in habitats marked by strong variations in solar radiation, air temperature and humidity, which are common in the different physiognomies of the Brazilian savannas.

\section{Acknowledgments}

Authors would like to thank Dr. Ciro C.Z. Branco that borrow the light sensor and Dra. Giselda Durigan for species identification.

\section{References}

Abrams, M.D.; Kubiske, M.E. \& Mostoller, S.A. 1994. Relating wet and dry year ecophysiology to leaf structure in contrasting temperate tree species. Ecology 75(1): 123-133.
Björkman, O. 1981. Pp. 57-107. Responses to different quantum flux densities. In: Lange, O.L.; Nobel, P.S.; Osmond, C.B \& Ziegler, H. (eds.). Encyclopedia of plant physiology. New York, Springer.

Boardman, N.K. 1977. Comparative photosynthesis of sun and shade plants. Annual Review of Plant Physiology 28: 355-377.

Catalan, C.A.N.; Vega, M.I.; Lopez, M.E.; Cuenca, M.R.; Gedris, T.E. \& Herz, W. 2003. Coumarins and a kaurene from Gochnatia polymorpha from Paraguay. Biochemical systematics and ecology 31: 417-422.

Cronquist, A. 1981. An integrated system of classification of flowering plants. New York, Columbia. University Press.

Dias, J.; Pimenta, J.A.; Medri, M.E.; Boeger, M.R.T. \& Freitas, C.T. 2007. Physiological aspects of sun and shade leaves of Litrhaea molleoides (Vell.) Engl. (Anacardiaceae). Brazilian Archives of Biology and Technology 50(1): 91-99.

Durigan, G.; Bacic, M.C.; Franco, G.A.D.C. \& Siqueira, M.F. 1999. Inventário florístico do cerrado na Estação Ecológica de Assis, SP. Hoehnea 26:149-172.

Durigan, G.; Melo, A.C.G.; Max, J.C.M.; Vilas Boas, O. \& Contieri, W.A. 2003. Manual para recuperação da vegetação do cerrado. São Paulo, Páginas e Letras.

Durigan, G.; Baitello, J.B.; Franco, G.A.D.C. \& Siqueira, M.F. 2004. Plantas do cerrado paulista: Imagens de uma paisagem ameaçada. São Paulo, Editora Páginas \& Letras.

Ehleringer, J.R.; Björkmann, O. \& Mooney, H.A. 1976. Leaf pubescence: effects on absorbance and photosynthesis in desert shrubs. Science 192: 376-377.

Ehleringer, J.R. \& Bjorkamann, O. 1978. Pubescence and leaf spectral characteristics in a desert shrub, Encelia farinosa. Oecologia 37: 183-200.

Fahn, A. 1964. Some anatomical adaptations of desert plants. Phytomorphology 14: 93-102.

Fahn, A. 1986. Structural and functional properties of trichomes of xeromorphic leaves. Annals of Botany 57: 631-637.

Fahn, A. \& Cutler, D. 1992. Xerophytes. Gebrüder Borntraeger, Berlin. 
Feller, I.C. 1996. Effects of nutrient enrichment on leaf anatomy of dwarf Rhizophora mangle L. (Red mangrove). Biotropica 28: 13-22.

Furley, P.A. 1999. The nature and diversity of neotropical savanna vegetation with particular reference to the Brazilian cerrado. Global Ecology Biogeography 8: 223-241.

Furley, P.A. \& Ratter, J.A. 1988. Soil resources and plant communities of the Central Brazilian cerrado and their development. Journal of Biogeography 15: 97-108.

Galmes, J.; Flexas, J.; Save, H. \& Medrano, H. 2007. Water relation and stomatal characteristics of Mediterranean plants with different growth forms and leaf habits: responses to water stress and recovery. Plant Soil 290: 139-155.

Gianoli, E. \& Gonzalez-Teuber, M. 2005. Environmental heterogeneity and population differentiation in plasticity to drought in Convolvulus chilensis (Convulvolaceae). Evolutionary Ecology 19: 603-613.

Givnish, T.J. 1984. Pp. 51-84. Leaf and canopy adaptations in tropical forests. In: Medina, E.; Mooney H.A. \& Vasques-Yanes, C. (eds.) Physiological ecology of plants in the wet tropics. The Hague, Dr. W. Junk Publishers.

Gomes, B.Z.; Martins, F.R. \& Tamashiro, J.Y. 2004. Estrutura do cerradão e da transição entre cerradão e floresta paludícola num fragmento da International Paper do Brasil Ltda., Em Brotas, SP. Revista Brasileira de Botânica 27(2): 249-262.

Gratani, L.; Covone, F. \& Larcher, W. 2006. Leaf plasticity in response to light of three evergreen species of the Mediterranean maquis. Trees 20: $549-558$.

Haridasan, M. 1992. Pp. 171-184. Observations on soils, foliar nutrient concentrations and floristic composition of cerrado sensu stricto and cerradão commuities in central Brazil. In: Furley, P.A.; Proctor A. \& Ratter, J.A. (eds.). Nature and Dynamics of Forest-Savanna Boundaries. London, Chapman and Hall

Haridasan, M. 2001. Pp. 68-83. Nutrient cycling as a function of landscape and biotic characteristics in the cerrados of Central Brazil. In: M.E. McClain; R.L. Victorial \& J.E. Richey (eds.). The biogeochemistry of the Amazon Basin. New York, Oxford University Press.

Hlwatika, C.N.M. \& Bhat, R.B. 2002. An ecological interpretation of the difference in leaf anatomy and its plasticity in contrasting tree species in Orange Kloog, table Mountain, South Africa. Annals of Botany 89: 109-114.

Isanogle, I.T. 1944. Effects of controlled shading upon the development of leaf structure in two deciduous tree species. Ecology 25: 404-413.

Jackson, L.W.R. 1967. Relation of leaf structure to shade tolerance of dicotyledonous tree species. Forest Science 13(3): 321-323.

Juhász, C.E.P.; Cursi, P.R.; Cooper, M.; Oliveira, T.C. \& Rodrigues, R.R 2006. Soil water dynamics in a toposequence under Savanna Woodland (Cerradão) in Assis,Sp, Brazil. Revista Brasileira de Ciências do Solo 30: 401-412.

Klich, M.G.; Brevedan, R.E. \& Villamil, S.C. 1997. Leaf anatomy and ultrastructure of Poa ligularis after defoliation and water strees. Proceedings of the $\mathbf{1 8}^{\text {th }}$ International Grassland Congress 1: 37-38.

Klich, M.G. 2000. Leaf variations in Elaeagnus angustifolia related to environmental heterogeneity. Environmental and Experimental Botany 44: 171-183.

Larcher, W. 2003. Physiological plant ecology. $4^{\text {th }}$ New York, Springer.

Lorenzi, H. 2002. Brazilian trees: A guide to the identification and cultivation of brazilian native trees. Nova Odessa, Plantarum.

Mantuano, D.G.; Barros, C.F. \& Scarano, F.R. 2006. Leaf anatomy variation within and between three "restinga" populations of Erythroxylum ovalifolium Peyr. (Erythroxylaceae) in Southeast Brazil. Revista Brasileira de Botânica 29(2): 209-215.
Medina, E.; Garcia, V. \& Cuevas, E. 1990. Sclerophylly and oligotrophic environments: Relationships between leaf structure, mineral nutrition content, and drought resistance in tropical rain forests of the upper Rio Negro region. Biotropica 22(1): 51-64.

Mendonça, R.C.; Felfili, J.M.; Walter, B.M.T.; Silva Júnior, M.C.; Rezende, A.V.; Filgueiras, T.S. \& Nogueira, P.E. 1998. Pp. 289-556. Flora Vascular do Cerrado. In: Sano, S.M. \& Almeida, S.P. (Eds.). Cerrado: ambiente e flora. Planaltina, EMBRAPA-CPAC.

Melo-de-Pinna, G.F.A. 2004. Anatomia foliar de Richterago Kuntze (Mutisieae, Asteraceae). Acta Botanica Brasilica 18(3): 591-600.

Milan, P.; Hayashi, A.H. \& Appezzato-da Glória, B. 2006. Comparative leaf morphology and anatomy of three Asteraceae species. Brazilian Archives of Biology and Technology 49: 135-144.

Oliveira Filho, A.T. \& Ratter, J.A. 2002. Pp. 91-120. Vegetation physiognomies and woody flora of the Cerrado Biome. In: Oliveira, P.S. \& Marquis, R.J. (eds.). The Cerrados of Brazil. New York, Columbia University Press.

Paiva, E.A.S.; Isaias, R.M.S.; Vale, F.H.A. \& Queiroz, C.G.S. 2003. The influence of light intensity on anatomical structure and pigment contents of Tradescantia pallida (Rose) Hunt. cv. purpurea Boom (Commelinaceae) leaves. Brazilian Archives of Biology and Technology 46: 617-624.

Pallardy, S.G. 1981. Pp. 56-78. Closely related woody plants. In: T.T. Kozlowski (ed.). Water deficits and plant growth, Vol. VI. New York, Academic Press.

Pearce, D.W.; Millard, S.; Bray, D.F. \& Rood, S.R. 2006. Stomatal characteristics of riparian poplar species in a semi-arid environment. Tree Physiology 26: 211-218.

Ratter, J.A. 1992. Pp. 417-429. Transitions between cerrado and forest vegetation in Brazil. In: Furley, P.A.; Proctor, A. \& Ratter, J.A. Nature and Dynamics of Forest-Savanna Boundaries. London, Chapman and Hall.

Ratter, J.A.; Ribeiro, J.F. \& Bridgewater, S. 1997. The Brazilian cerrado vegetation and threats to its biodiversity. Annals of Botany 80: 223-230.

Sacilotto, A.C.B.C.; Vichnewski, W. \& Herz, W. (1997), Ent-kaurene diterpenes from Gochnatia polymorpha. Phytochemistry 44(4): 659-661.

Sajo, M.G. \& Menezes, N.L. 1994. Considerações sobre a anatomia foliar de espécies de Vernonia Screb. (Compositae) da Serra do Cipó, MG. Naturalia 19: 173-183.

Scheiner, S.M. 1993. Genetics and evolution of phenotypic plasticity. Annual Review of Ecology and Systematics 24: 35-68.

Secretaria do Meio Ambiente. 1997. Estação Experimental e Ecológica de Assis. São Paulo, Secretaria do Meio Ambiente.

Shields, L.M. 1950. Leaf xeromorphy as related to physiological and structural influences. Botanical Reviews 16: 399-477.

Smith, W.K.; Vogelmann, T.C.; De Lucia, E.H.; Bell, D.T. \& Shepherd, K.A. (1997), Leaf form and photosynthesis. Bio-Science 47: 785-793.

Stearns, A.D. 1989. The evolutionary significance of phenotypic plasticity. Bioscence 39: 436-445.

Tabanez, M.F.; Durigan, G.; Keuroghlian, A. \& Barbosa, A.F. 2005. Plano de manejo da Estação Ecológica dos Caetetus. IF Série Registros 29: 1-104.

Turner, I.M. 1994. Sclerophylly: primarily protective? Functional Ecology 8: 669-675.

Via, S. 1993. Adaptive phenotypic plasticity: target or by-product of selection in a variable environment. The American Naturalist 142: 352-365.

Vogelmann, T.C. 1993. Plant tissue optics. Annual Review Plant Physiological and Plant Molecular biology 44: 231-251.

Weyers, J.D.B. \& Meidner, H. 1990. Methods in stomatal research. London, Longman. 